\title{
TINJAUAN PSIKOLOGI AGAMA TENTANG NAFSU SEBAGAI GEJALA JIWA ANAK
}

\author{
Oleh: Suriyati ${ }^{1}$
}

\begin{abstract}
Abstrak
Tulisan ini akan menfokuskan pembahasan pada dua aspek pokokya itu bagaimana gejala jiwa anak yang ditimbulkan oleh nafsu menurut tinjauan psikologi agama dan langkah-langkah yang ditempuh untuk mengendalikan hafsu kearah yang positif menurut tinjauan psikologi agama.

Adapun kesimpulan tulisan ini yaitu:bahwa dengan tinjauan psikologi agama dimana nafsu sebagai gejala jiwa anak, memberikan kajian bahwa dengan pengendalian nafsu, bimbingan yang kontinyu serta kedekatan kasih sayang, maka pengendalian diri, dan emosi seorang anak dapat diarahkan kearah yang baik sehingga menjadi pribadi yang berakhlak dan berprilaku yang sesuai dengan tuntunan Agama Islam, disamping itu, peranan keluarga sebagai pendidikan yangb utama dan utama menjadi jembatan dan langkah-langkah dalam menuntun kepribadian anak menuju pribadi yang positif, selain beberapa pengaruh dan tindakan, seperti pergaulan dan lingkungan serta langkah-langkah yang ditempuh untuk mengendalikan nafsu kearah yang positif menurut tinjauan psikologi agama adalah dengan meningkatkan nilai-nilai keimanan dan ketaqwaan kepada Allah swt, kapan dan dimana saja sehingga jiwa manusia akan kembali kearah yang positif untuk mencapai tingakat muttaqin, mendirikan shalat lima waktu dengan khusyu, tafakku dan zikir serta senantiasa meningkatkan pemahaman dan pengamalan ibadah shalat wajib dan sunnah, puasa, zakat dan membaca al-Qur'an dengan penuh perhatian.
\end{abstract}

Kata kunci: Nafsu dan gejala jiwa anak

\section{PENDAHULUAN}

Setiap manusia muslim berkewajiban untuk menjadikan suri tauldan, akhlak dan perilaku luhur dan mulia yang dimiliki oleh junjungan kita Nabi Beasr Muhammad saw. Untuk itu manusia muslim harus mengetahui bagaiaman akhlakul kharimah dan sikap yang terpuji serta tindakan yang diajarkan dan diperlihatkan oleh beliau di kala hidupnya, karena seluruh perilaku dan tindakannya itu merupakan suatu panutan dan ikutan bagi setiap muslim dan diantara sekian banyak akhlak luhur dan kemuliaan beliau miliki adalah sikap yang teguh dalam kehidupan ini. Demikian, kesemua pandangan ini hanya dipahami oleh orang-orang yang beriman khususnya

\footnotetext{
${ }^{1}$ Dosen tetap pada Institut Agama Islam Muhammadiyah Sinjai
} 
kalangan orang tua yang senantiasa memikirkan dan merenungkan akan kebesaran Allah swt, melalui ayat-ayatNya baik yang tertulis dalam al-Qur'an maupun ayatayat-Nya yang hanya dapat dilihat dari gejala alam. Sebaliknya bagi orang-orang yang selalu pesimis dan tidak memperhatikan gejala-gejala alam tentu pengaruhnya amat sedikit dalam memahami kebesara-Nya.

Perkembangan anak dewasa ini, dimana perilaku anak dewasa ini memperlihatkan kecendrungan yang amat jauh dari prilaku kehidupab seseorang muslim, dimana sikap dan prilaku anak sebagaai suatu gejala jiwa menunjukkan adanya sikap dan tindakannya yang mengarah pada sikap kurang berpikir sebelum bertindak, kurang positif dalam melakukan aktivitas dan kurang menerima dengan lapang dada dan penuh keikhlasan dari segala apa yang sudah menjadi keputusan yang diturunkan Allah swt. Sehubungan dengan itu, Allah swt berfirman dalam alQur'an surah al fajr : 27-30 sebagai berikut: ${ }^{2}$

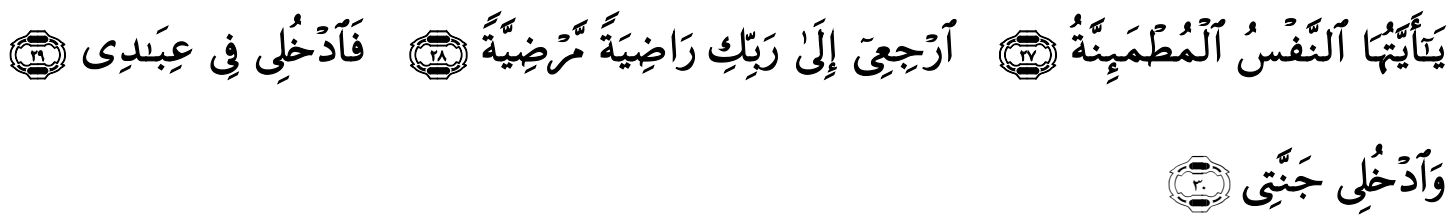

Terjemahnya:

Wahai jiwa yang mencapai ketentraman, kembalilah kepada Tuhanmu dalam keadaan ridha dan diridhai, maka masukla kedalam golongan hamba-hambaKu dan masuklah kedalam surga-Ku.

Dari pemahaman ayat tersebut diatas, memberikan peringatan kepada setiap manusia muslim yang mempunyai jiwa agar dapat memiliki nilai kepuasan dalam beriman sebagai hasil pembinaan dan pendidikan yang didapatkannya dan mampu memberi bimbingan kepada anaknya sehingga segala tindakan amal perbuatan hidupnya senantiasa mendapatkan keridhaan Allah swt.

Oleh karena itu dengan ketenangan jiwa menjalankan syariat agama, maka kita dapat merasakan kenikmatan kebahagiaan baik didunia maupun diakhirat serta mengharapkan perbuatan dan prilaku anak senantiasa penuh amal ibadah sehingga mereka dapat digolongkan kedalam golongan hamba-hambaNya yang diridhoi dan menjadi penghuni surga. Dalam kontek ketenangan jiwa setiap anak dapat memiliki kemampuan yaitu kemampuan untuk mengendalikan hawa nafsunya, bukan sebaliknya kelembah kenistaan. Oleh karena itu nafsu merupakan suatu proses

\footnotetext{
${ }^{2}$ Departemen Agama RI, Al-Qur'an dan Terjemahnya (Jakarta: Yayasan Penyelenggara dan Pnterjemah/Penafsir Al-Qur'an. 1980) h. 1057
} 
dimana perubahan kepribadian seseorang akan Nampak berdasarkan pengedalian nafsunya.

Jiwa ruhaniah berpokok kepada rasio dan logika, manusia merupakan bagian jiwa yang tertinggi, sedang jiwa badaniah sendiri dibagi menjadi dua bagian yaitu kemauan dan nafsu perasaan. Dengan demikian, jiwa manusia terdiri dari atas unsur kecerdasan, kemauan dan nafsu perasaan, ketiga unsur jiwa itu masin-masing mempunyai tempatnya dalam manusia yaitu kecerdasan di kepala, kemauan di dada, dan nafsu perasaan diperut. ${ }^{3}$ Sehubungan dengan hal tersebut, maka Allah swt menegaskan dalam surah Ar-Ra'du ayat 28 yaitu: ${ }^{4}$

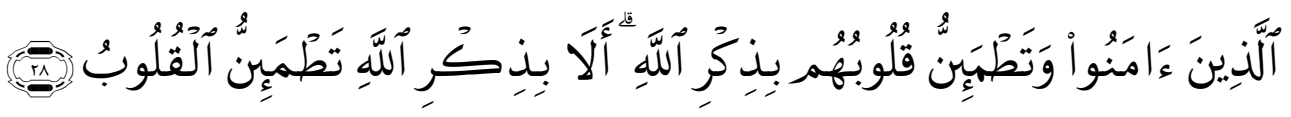

Terjemahnya:

(yaitu) orang-orang yang beriman dan hati mereka manjadi tenteram dengan mengingat Allah. Ingatlah, hanya dengan mengingati Allah-lah hati menjadi tenteram.

Oleh karena itu, gejala jiwa bagi seorang muslim, ketenangan dan ketentramannya sangat bergantung pada nilai keimanannya dalam mengarungi bahtera kehidupan untuk menjadi bekal dalam kehidupan diakhirat nanti.

\section{PEMBAHASAN}

\section{A. Teori psikologi agama}

\section{Pengertian psikologi}

Menurut bahasa kata psikologi merupakan hasil peng Indonesiaan, dari bahasa Inggris Psychologi, dan istilah ini pun berasala dari kata Yunan yaitu: Psycho dapat diartikan "roh, jiwa atau jiwa hidup" dan logos dapat diartikan "ilmu". Dengan demikian, secara harfiah psikologi adalah ilmu jiwa. Sedangkan menurut istilah ( Muhibbin Syah, 1995: 7-10) dalam buku psikologi pendidikan suatu pendekatan baru telah terjadi perbedaan pendapat, sesuai dengan disimplin ilmu yang dimilikinya, seperti:

\footnotetext{
${ }^{3}$ Singgih, D. Gunarso, Pengantar Psikologi, (Jakarta, Mutiara. 1978), h.9

${ }^{4}$ Departemen Agama RI, Al-Qur'an dan Terjemahnya (Jakarta: Yayasan Penyelenggara dan Pnterjemah/Penafsir Al-Qur'an. 1980) h. 1057

${ }^{5}$ Abu Ahmadi, Psikologi Sosial (Cet I: Jakarta: PT Rineka Cipta, 1991), h. 1
} 
1. Pendapat Muhiddin Syah adalah ilmu yang mengenai kehidupan mental, ilmu mengenai pikiran dan ilmu mengenai tingkah laku.

2. Pendapat Gleitman adalah "ilmu pengetahuan yang berusaha memahami prilaku manusia, alasan dan cara mereka melakukan sesuatu juga memahami bagaimana akhlak tersebut dapat berfikir dan berperasaan secara sesungguhnya"

3. Pendapat chalpin adalah "ilmu pengetahuan mengenai prilaku manusia dan hewan, juga menyelidiki terhadap organism dalam segala ragam dan kerumitannya ketika mereaksi arus dan perubahan alam sekitar dan peristiwa-peristiwa kemasyarakatan yang mengubah lingungan. ${ }^{6}$

\section{Pengertian Agama}

Begitu juga dengan agama menyangkut masalah yang berhubungan dengan kehidupan batin manusia. Agama sebagai bentuk keyakinan, meman sulit di ukur secara tepat dan rinci, kesulitan dalam memberikan defenisi agama karena pengalaman agama bersifat subyektif dan mendalam. Pengaruh agama sangat dominan terhadap perasaan dan kepribadian sesorang sedangkan unsure subyektif juga sangat dalam mempengaruhi pengertian agama. ${ }^{7}$ Banyak ahli yang berpendapat tentang arti agama, diantaranya:

1. Menurut Harun Nasution, arti agama berdasarkan asal kata yaitu al-din, religi (relege, religare) dan agama dalam bahasa semit al-din berarti undang-undang atau hokum. Dalam bahasa Arab Agama (Ad-din) artinya hokum, ikatan, dan peraturan sedangkan dalam bahasa latin, kata religi (relege) berarti mengumpulkan dan membaca yang kemudian menjadi kata religare yang berarti mengikat. $^{8}$

2. Agama adalah ikatan yang harus dipegan dan dipenuhi manusia, ikatan adalah kekuatan yang lebih tinggi dari manusia yang tidak dapat ditangkap keduanya, namun mampu mawarnai kehidupan.

3. Menurut Harun Nasution, agama harus mempunyai 4 aspek yaitu: kekuatan gaib, keyakinan terhadap kekuatan gaib, respon, paham adanya yang kudus. ${ }^{9}$

Menurut Robert H. Thouless, fakta menunjukkan bahwa agama berpusat pada Tuhan atau Dewa, Deawa sebagai ukuran yang menentukan yang tidak boleh diabaikan (keyakinan tentang dunia lain). Ia mendefinisikan agama adalah sikap atau

\footnotetext{
${ }^{6}$ Abu Ahmadi, “Psikologi Umum”, (Jakarta: Rineka Cipta, 2003), h. 118

${ }^{7}$ Drs.H. Aziz Ahyadi, Psikologi Agama, Mertiana Bandung, h. 9-10

${ }^{8}$ Prof Dr. H. Ramayulis, Psikologi Agama, Kalam Mulia 2004, h. 1

${ }^{9}$ Ibid, h. 5
} 
acara penyesuaian diri terhadap dunia yang mencakup acuan yang menunjukkan lingkungan lebih luas daripada dunia fisik yang terikat ruang dan waktu (dunia spiritual). ${ }^{10}$

\section{Pengertian Psikologi Agama}

Berhubungan dengan hak ini, Taules berpendapat bahwa psikologi agama adalah cabang dari psikologi yang bertujuan mengembangkan pemahaman terhadap perilaku keagamaan dengan mengaplikasikan prinsip-prinsip psikologi yang dipungut dari kajian terhadap perilaku bukan keagamaan. Sedangkan menurut Zakiah Darajat, psikologi agama adalah meneliti dan menelaah kehidupan beragama pada seseorang yang mepelajari berapa besar pengaruh keyakinan agama itu dalam sikap dan tingkah laku serta keadaan hidup pada umumnya. Disamping itu psikologi agama juga mempelajari pertumbuhan dan perkembangan jiwa agama pada seseorang serta factor-faktor yang mempengaruhi keyakinan tersebut. ${ }^{11}$

Sehubungan dengan psikologi agama Jalaluddin berpendapat bahwa psikologi agama menggunakan dua kata yaitu psikologi dan agama, kedua kata ini memiliki pengertian yang berbeda. Dimana psikologi secara umum diartikan sebagai ilmu yang mempelajari gejala jiwa manusia yang normal, dewasa dan beradab. ${ }^{12}$

\section{B. Tinjauan Tenatang Nafsu dan Jiwa}

\section{Pengertian Nafsu}

Nafsu secara etimologi berarti jiwa, adapun nafsu secara terminologis ilmu menurut ilmu tasawuf adalah dorongan alamiah manusia untuk pemenuhan kebutuhan hidupnya. Hawa nafsu adalah suatu yang disenangi oleh jiwa kita yang cendrung negative, baik bersifat jasmani yaitu sesuatu yang berkaitan dengan tubuh kita seperti makanan, minuman dan kebutuhan biologis lainnya, nafsu yang bersifat maknawai yaitu nafsu yang berkaitan dengan kebutuhan rohani seperti nafsu seperti ingin diperhatikan oran lain, ingin dianggap sebagai orang yang paling penting, paling pintar dan lain-lain. Dari segi tahapan nafsu terbagi menjadi tiga bagian.

a. Nafsu Amarah yaitu cendrung kepada kesenagan-kesenangan yang rendah yaitu kesenangan yang bersifat duniawi. Nafsu ini berada pada tahap pertama yang golongan sangat rendah, karena yang memiliki nafsu ini cendrung kepada

${ }^{10}$ H. Endang Saifuddin Anshari M. A. Ilmu, Filsafat dan Agama, Penerbit Bina Ilmu 1979, h.

${ }^{11}$ Prof. Dr. Ramayulis, Psikologi Agama, Kalam Mulia 2004, h.1

12 Agus M. Harjana, Perkembangan Kepribadian dan keagamaan, Yogyakarta: Kanisius, cet, 
perbuatan-perbuatan yang maksiat. Allah berfirman dalam al-Qur'an surah Yusuf: $53 .^{13}$

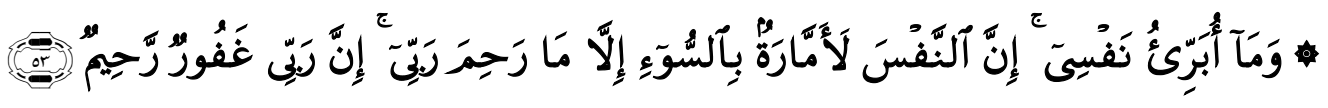

Terjemahnya:

Dan aku tidak membebaskan diriku (dari kesalahan), karena Sesungguhnya nafsu itu selalu menyuruh kepada kejahatan, kecuali nafsu yang diberi rahmat oleh Tuhanku. Sesungguhnya Tuhanku Maha Pengampun lagi Maha Penyanyang.

b. Nafsu Lauwamah yaitu jiwa yang sudah sadar dan mampu melihat kekurangankekurangan diri semdiri, dengan kesadaran itu ia terdorong untuk meninggalkan perbuatan-perbuatan rendah dan selalu berupaya melakukan sesuatu yang mengantarkan kebahagiaan yang bernilai tinggi.

Ustaz arifin Ilham Mengatakan, bahwa orang masih memiliki nafsu lauwamah ini biasanya disaat ia melakukan maksiat/dosa maka akan timbul penyesalan dalam dirinya, namun dalam kesempatan lain ia akan mengulangi maksiat tersebut yang juga akan diiringi dengan penyesalan-penyesalan kembali. Selain itu ia menyesal kenapa ia tidak banyak berbuat kebaikan lebih banyak. Di dalam al-Qur'an surah alQiyamah: $2^{14}$

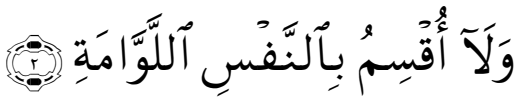

Terjemahnya: dan aku bersumpah dengan jiwa yang Amat menyesali (dirinya sendiri).

c. Nafsu Mutmainnah Yaitu jiwa tenang, Karena nafsu ini tergolong tahap tinggi, nafsu yang sempurna berada dalam kebenaran dan kebajikan, itulah nafsu yang dipanggi dan dirahmati oleh Allah swt sebagaimana firman-Nya, Qur'an surah alFajr: $27-28^{15}$

${ }^{13}$ Departemen Agama RI, Al-Qur'an dan Terjemahnya (Jakarta: Yayasan Penyelenggara dan Pnterjemah/Penafsir Al-Qur'an. 1980

${ }^{14}$ Departemen Agama RI, Al-Qur'an dan Terjemahnya (Jakarta: Yayasan Penyelenggara dan Pnterjemah/Penafsir Al-Qur'an. 1980

15 


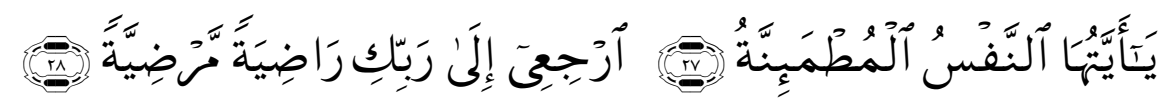

Terjemahnya:

Hai jiwa yang tenang. Kembalilah kepada Tuhanmu dengan hati yang puas lagi diridhai-Nya.

\section{Pengertian Jiwa}

Kata jiwa berasal dari bahasa arab yaitu nafs' yang secara harfiah bias diterjemahnkan sebagai jiwa, dalam bahasa inggris disebut soul atau spirit, Secara istilah, kata jiwa dapat merujuk pada beberapa pandangan ulama dan filusuf muslim terutama al-Kindi dan Ibnu Sina umumnya sepakat mendefenisikan bahwa jiwa adalah kesempurnaan awal bagi fisik yang bersifat alamiah, mekanistik dan memiliki kehidupan yang energik. ${ }^{16}$ Secara lebih rinci yang dimaksud dengan kesempurnaan bagi fisik yang bersifat alamiah adalah bahwa manusia dikatakan menajdi makhluk yang sempurna ketika menajdi makhluk yang bertindak, sebab jiwa merupakan kesempurnaan pertama bagi fisik alamiah bukan pada fisik buatan. Kemudian makna mekanistik adalah bahwa badan menjalankan fungsinya melalui perantara alat-alat yaitu anggota tubuhnya yang beragam. Sedangkan makna memiliki kehidupan yang energik adalah bahwa didalam dirinya terkandung kesiapan hidup dan persiapan untuk menerima jiwa. Adapun pembagian gejala jiwa pada anak antara lain:

\section{a. Gejala pengenalan (kognisi)}

Istilah cognitive berasal dari kata cognition yang padanan katanya knowing berarti mengetahui, dalam arti luas yaitu perolehan, penataan, dan penggunaan pengetahuan dalam perkembangan selanjutnya. Setiap prilaku mental yang berhubungan yang berhubungan dengan pemahaman, perimbangan, pengolahan informasi, pemecahan masalah, kesenjangan dan keyakinan. ${ }^{17}$

Berikut ini skema gejala pengenalan atau kognisi

\begin{tabular}{|c|c|c|}
\hline \multirow[t]{2}{*}{$\begin{array}{l}\text { Gejala Pengenalan } \\
\text { (kognisi) }\end{array}$} & Tingkat rendah & $\begin{array}{l}\text { 1. Pengamatan } \\
\text { 2. Tanggapan } \\
\text { 3. Fantasi } \\
\text { 4. Daya ingatan }\end{array}$ \\
\hline & Tingkat tinggi & $\begin{array}{l}\text { 1. Berfikir } \\
\text { 2. Intelegensi }\end{array}$ \\
\hline
\end{tabular}

${ }^{16}$ Abu Ahmadi, Psikologi Umum, (Jakarta: Rineka Cipta, 2009), h. 72

${ }^{17}$ M. Ishom Ahmadi, Op.Cit, h. 29 


\section{b. Gejala kemauan (konasi)}

Kemauan merupakan salah satu dari fungsi kejiwaan manusia, dapat diartikan aktifitas psikis yang mengandung usaha aktif dan berhubungan dengan pelaksanaan tujuan. Tujuan adalah titik akhir dari gerakan yang menuju suatu arah. Dalam istilah sehari-hari kemauan dapat disamakan dengan kehendak atau hasrat. Kehendak ialah suatu fungsi jiwa untuk dapat mencari sesuatu. Kehendak ini merupakan kekuatan dari dalam dan tanpak dari luar sebagai gerak-gerik. ${ }^{18}$

\section{c. Gejala perasaan (emosi)}

Perasaan termasuk gejala jiwa yang dimiliki oleh semua orang dan tingkatannya tidak sama. Perasaan tidak termasuk gejala mengenal, walaupun demikian perasaan sering juga berhubungan dengan gejala mengenal. ${ }^{19}$ Atau perasaan dapat juga diartikan sebagai suasana psikis yang mengambil bagian pribadi dalam situasi dengan jalan membuka diri terhadap suatu hal yang berbeda dengan keadaan atau nilai dalam diri. ${ }^{20}$

\section{Gejala perkembangan Jiwa anak yang ditimbulkan oleh Nafsu menurut Tinjauan Psikologi Agama}

Dalam pembahasan perkembangan jiwa anak yang ditimbulkan oleh nafsu menurut tinjauan psikologi agama, penulis akan menguraikan berbagai perkembangan atau gejala jiwa anak. Masalah yang selalu diarahkan orang tua tentang anak mereka seakan-akantidak pernah berakhir. Taraf pertumbuhan dan perkembangan telah menjadikan perubahan pada diri anak. Perubahan prilaku tidak akan menjadi amsalah bagi orang tua apabila anak tidak menunjukkan tanda penyimpangan. Akan tetapi, apabila anak telah menunjukkan tanda yang mengarah ke hal negative akan membuat cemas bagi sebagai orang tua.

Kecemasan orang tua disebabkan oleh timbulnya perbuatan negative anak sebagai suatu proses perkembangan jiwa yang terkadang dipengaruhi oleh nafsu yang dapat merugikan masa depannya. Kekhwatiran orang tua ini cukup beralasan sebabanak kemungkinan akan berbuat apa saja tanpa berpikir risiko yang akan ditanggungnya. Biasanya penyesalan datang setelah anak menanggung risiko atas perbuatanya.

Menurut Clemes bahwa terjadinya penyimpangan perilaku anak disebabkan kurangnya ketergantungan antara anak dengan orang tua. Hal ini terjadi karena antara

\footnotetext{
${ }^{18}$ Abu Ahmadi, Psikologi Umum, (Jakarta: Rineka Cipta, 2003), h.94

${ }^{19}$ Abu Ahmadi, Psikologi Belajar, (Jakarta: Rineka Cipta, 1991), h. 36

${ }^{20}$ Wasti Soemanto, Psikologi Pendidikan, (Jakarta: Rineka Cipta, 1998), h.36
} 
anak dan orang tua tidak pernah sama dalam segala hal. Ketergantungan anak kepada orang tua ini dapat terlihat dari keinginan anak untuk memperoleh perlindungan, dan asuhan dan dari orang tua dalam segala aspek kehidupan. Selain itu, anak anak yang menjadi "masalah" kemungkinan terjadi akibat dari tidak berfungsinya system social dilingkungan tempat tinggalnya. Dengan kata lain perilaku anak merupakan reaksi atas perlakuan lingkungan terhadap dirinya. ${ }^{21}$

Menurut Zakiyah Daradjat, ruang lingkup yang menjadi lapangan kajian psikologi agama mengenai. $^{22}$

1. Bermacam-macam emosi yang menjalar di luar kesadaran yang ikut serta dalam kehidupan beragama, contoh: perasaan tenang, pasrah dan menyerah

2. Bagaimana perasaan dan pengalaman seseorang secara individual terhadap Tuhannya, contohnya: kelegaan batin.

3. Mempelajari, meneliti dan menganalisis pengaruh kepercayaan akan adanya hidup sesudah mati.

4. Meneliti dan mempelajari bagaimana pengaruh penghayatan seseorang terhadap ayat-ayat suci kelegaan batinnya.

\section{Langkah-langkah yang ditempuh untuk mengendalikan nafsu kearah yang postif menurut tinjauan Psikologi Agama.}

Pembahasan ini, penulis mencoba memberikan gambaran bahwa beberapa langkah-langkah yang dapat dilakukan dalam upaya mengendalikan nafsu seseorang anak menuju pada prilaku yang positif berdasarkan tinjauan psikologi agama.

\section{Pengendalian hawa nafsu}

Nafsu adalah jiwa manusia dalam kehidupan didunia. Ketika berada dalam janin di rahim ibunya, nafsu disebut juga sebagai ruh, begitu lahr dia disebut sebagai nafsu. Masing-masing nafsu yang memiliki dua sisi ini tidak boleh terlalu diikuti keinginannya, walaupun nafsu yang kelihatanya baik, berbuat baik cukup biasabiasa saja, jangan terlalu berlebihan, perbuatan yang kelihatanya terpuji tersebut hanyalah perasaan ingin terkenal dan dipuji orang dan diantara mereka ada yang mendengarkan perkataanmu tapi tidak mengacuhkannya, sehingga manakalah mereka keluar dari tempatmu, mereka bertanya kepada orang-orang yang telah dapat ilmu "Apakah yang dikatakannya tadi? Itulah orang-orang yang yang telah ditutup mata hatinya oleh Allah, mereka mengikuti segala keinginan nafsunya. Allah swt berfirman dalam al-Qur'an surah Muhammad: $16^{23}$

\footnotetext{
${ }^{21}$ Clemes, Harris. 2001, Mengajarkan Disiplin Kepada Anak, (Jakarta: Mitra Utama), h. 23

${ }^{22}$ Zakiyah Darajat, Ilmu Jiwa Agama (Cet IV: Jakarta NV. Bulan Bintang, 1993), h.3

${ }^{23}$ Departemen agama RI, Al-Qur'an dan Terjemahnya (Jakarta: Yayasan Penyelenggara Pneterjemah/penafsir Al-Qur'an, 1980)
} 


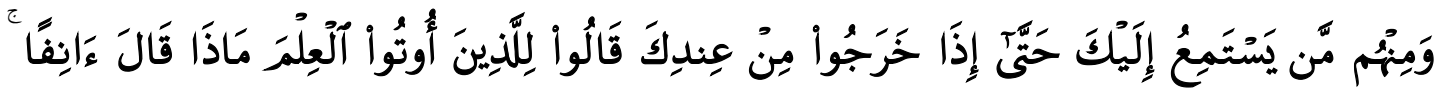

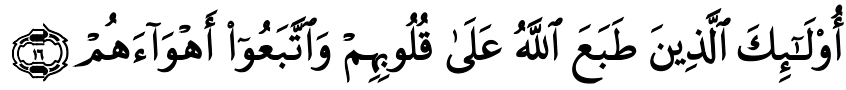

Terjemahnya:

dan di antara mereka ada orang yang mendengarkan perkataanmu sehingga apabila mereka keluar dari sisimu orang-orang berkata kepada orang yang telah diberi ilmu pengetahuan (sahabat-sahabat Nabi): "Apakah yang dikatakannya tadi?" mereka Itulah orang-orang yang dikunci mati hati mereka oleh Allah dan mengikuti hawa nafsu mereka.

\section{Peningkatan Moral yang baik}

Dalam kajan ini, maka persoalan moral diaman suatu moral dapat berlaku obyektif dan dapat juga subyektif. Moral obyektif memandang perbuatan manusia sematasebagai suatu perbuatan yang telah dikerjakan, bebas lepas dari pengaruh pihak pelaku kehidupan manusia, sejak zaman dulu hingga sekarang tidak pernah lepas perbuatan baik dan buruk. Moral juga merupakan standar kualitas perbuatan manusia, terutama terkait dengan pola laku dan tindakannya. Dari laku dan tindakanya yang mengaktualisasi di ruang social itulah akan didapati mana perbuatan yang benar atau salah.

Menurut perspektif islam, moral ini biasanya disebut dengan istilah akhlak. Akhlak yang diajarkan di dalam la-Qur'an bertumpuh pada aspek fitrah yang terdapat didalam diri manusia, dari aspek wahyu (agama) kemudian kemauan dan tekad manusiawi.

\section{Menjaga ketaantan kepada Allah}

Sudah menjadi fitrah manusia, bahwa kebutuhan dirinya harus lebih diutamakan daripada kebutuhan orang lain. Menurut DR. Jalaluddin Rakhmat, ada beberapa hal yang harus diperhatikan agar tidak terperosok oleh hawa nafsu antara lain:

a. Bersikap ikhlas dan bening hati setiap memulai dan mengerjakan sesuatu.

b. Berupaya menjauhkan diri dari setiap sarana dan sumber pemicu kemaksiatan.

c. Berupaya menyeleksi teman, lingkungan dan sumber informasi.

d. Membiasakan diri berzikir mengingkat Allah dan meningkatkan ibadah.

e. Mempertimbangkan akibat-akibat kerugian yang ditimbulkan karena memperturutkan nafsu. 


\section{PENUTUP}

A. Kesimpulan

Berdasarkan hasil pengkajian dari beberapa dokumen, literature dan refrensi tentang gejala jiwa anak yang dipengaruhi oleh nafsu dipandang dari sudut psikologi agama, maka penulis merumuskannya bahwa perkembangan jiwa anak sengat mempengaruhi upaya pemanfaatn nafsu dengan baik sehingga dapat melahirkan kepribadian, etika dan moral anak diamana peran keluarga, lingkungan dan nilai keagamaanya sangat mendukung terbentuknya suatu kepribadian yang diharapkan dalam ajaran Islam.

Langkah-langkah yang dapat mengendalikan nafsu kearah yang positif menurut pandangan psikologi adalah membangun lingkungan, tradisi dan kebiasaan yang islami, baik dalam kehidupan rumah tangga, maupun diluar lingkungan. Membiasakan menerima pemahan tentang konsep Illahi, membangun rasa kepedulian, kemanusiaan dan yang lebih pokok adalah bagaimana memberikan bimbingan sejak dini kepada anak tentang pemahaman konsep agama Islam. Dalam pandangan itu, maka penulis merumuskan pendekatan psikologi agama dalam mencapai tingkat nafsu yang baik dengan mengupayakan adanya pembentukan kepribadian yang utuh bagi seorang anak. Karena dengan kepribadian seseorang itu merupaka keseluruhan jasmani dan rohani atau keprbadian yang terdiri dari lahir dan bathin, dengan demikian maka nafsu yang dimanfaatkan dengan baik atau kearah yang positif akan melahirkan kepribadian yang utama bagi seseorang menurut ajaran islami.

\section{B. Saran-saran}

Perkembangan jiwa anak dewasa ini sungguh mengalami perbedaan yang besar jika dbandingkan dengan kondisi perkembangan anak pada zaman dulu pengaruh kemajuan tekhnologi, pengetahuan, dan perubahan budaya membuat perkembangan jiwa anak mengalami kemajuan yang pesat, olehnya itup pembinaan, perhatian, pendampingan, baik orang tua, guru, maupun lingkungan bermainya sangat perlu dilakukan pemantauan.

Upaya mengendalikan nafsu agar dapat menjadikan langkah positif bagi anak, maka kebiasaan, tradisi dalam rumah tangga seperti mengaji, sahalat bertutur yang sopan, bersikap dan bergaul yang baik menjadi kehidupan dikeseharian anak. 